\title{
Homogeneity tests and non-parametric analyses of tendencies in precipitation time series in Keszthely, Western Hungary
}

\author{
Tímea Kocsis ${ }^{1}$ (D) - Ilona Kovács-Székely ${ }^{1}$ - Angéla Anda ${ }^{2}$
}

Received: 15 May 2019 / Accepted: 23 September 2019 / Published online: 7 November 2019

(C) The Author(s) 2019

\begin{abstract}
This study aims to investigate the precipitation trends in Keszthely (Western Hungary, Central Europe) through an examination of historical climate data covering the past almost one and a half centuries. Pettitt's test for homogeneity was employed to detect change points in the time series of monthly, seasonal and annual precipitation records. Change points and monotonic trends were analysed separately in annual, seasonal and monthly time series of precipitation. While no break points could be detected in the annual precipitation series, a significant decreasing trend of $0.2-0.7 \mathrm{~mm} / \mathrm{year}$ was highlighted statistically using the autocorrelated Mann-Kendall trend test. Significant change points were found in those time series in which significant tendencies had been detected in previous studies. These points fell in spring and winter for the seasonal series, and October for the monthly series. The question therefore arises of whether these trends are the result of a shift in the mean. The downward and upward shift in the mean in the case of spring and winter seasonal amounts, respectively, leads to a suspicion that changes in precipitation are also in progress in these seasons. The study concludes that homogeneity tests are of great importance in such analyses, because they may help to avoid false trend detections.
\end{abstract}

\section{Introduction}

There is no doubt that global warming and climate change represent a potential hazard to human socio-economic systems and our present way of life. The IPCC AR 5 (2013) gives a detailed description on the basis of scientific findings of the physical driving forces of climate change and the potential consequences that it is likely humanity will have to face in the future. Since changes in global climate should not and cannot be avoided, adaptation and mitigation are of the highest importance. The member states of the European Union are leaders in the mitigation of the effects of climate change, and lead the way in the development of a model for the advance of national climate adaptation and mitigation strategies (Pietrapertosa et al. 2018). Hungary has developed

Tímea Kocsis

JakuschneKocsis.Timea@uni-bge.hu

1 Department of Methodology, Faculty of Commerce, Catering and Tourism, Budapest Business School, University of Applied Sciences, Alkotmány St 9-11, Budapest 1054, Hungary

2 Georgikon Faculty Department of Meteorology and Water Management, University of Pannonia, Festetics St 7, Keszthely H-8360, Hungary its own National Adaptation Strategy and Policy within the framework of the European countries. According to a study by Aguiar et al. (2018), 11 Hungarian municipalities developed their own climate adaptation strategies between 2007 and 2013. In the case of Europe-wide adaptation funding, large municipalities tend to organize this locally, but for smaller urban units and rural areas, international and national funding is of greater importance (Aguiar et al. 2018).

Changes in precipitation have serious effects on human society and are the focus of investigation in many scientific fields, e.g. hydrology, agriculture and environmental sciences (Zhao et al. 2018). Rain gauges deliver the only direct measurement of point precipitation, providing a basic source or reference for precipitation related studies despite the inevitable uncertainties (Schroeer et al. 2018; Sun et al. 2018). Applied worldwide, rain gauges measure precipitation amounts accurately close to the ground (Schroeer et al. 2018).

Changes in precipitation trends and wet conditions because of climate change are not uniform globally, nor are these processes the same across Europe. Spinoni et al. (2017) used a standardised precipitation index (SPI) driven by precipitation to describe tendencies in meteorological droughts (1950 2015), and their results show a significant tendency toward less frequent and severe droughts over North-Eastern Europe (especially in winter and spring), and a moderate opposite 
trend over Southern Europe (especially in spring and summer). Between 1980 and 2015, the researchers found a significant tendency toward drier conditions in Central Europe in spring. Spinoni et al. (2015) reported that in Central Europe and the Balkans, drought variables show a moderate increase. Long-term (over a period of 120 years) trends in precipitation characteristics were analysed by Kumar et al. (2013) using data from three Italian weather stations (in Florence, Pisa and Palermo). A highly significant negative trend was found in the number of rainy days at Florence and Pisa, and negative tendencies were detected in the annual precipitation amount at Pisa and Palermo (Kumar et al. 2013). A 124-year precipitation time series was analysed by Pakalidou and Karacosta (2018) for Thessaloniki in Greece using the Mann-Kendall trend test, and a positive trend was detected in the annual data and for spring, autumn and winter. The only negative tendency among the seasonal analyses was the trend of the summer precipitation amount (Pakalidou and Karacosta 2018). Besides these long-term trends, the intensity of precipitation may also change. Irannezhad et al. (2016) reported that in Finland the annual number of occasions on which very light precipitation occurred significantly decreased between 1908 and 2008. Madsen et al. (2014) summarized the trend analysis and climate change projections of extreme precipitation and floods for the territory of Europe in a review. There is evidence that a general increase in the incidence of extreme precipitation is likely in the future in Europe (Madsen et al. 2014). Pinskwar et al. (2019) examined the changes of precipitation extremes in Poland for the period 1961-2015, and found that daily maximum precipitation increased for the summer half-year, and most of the statistical indices of the time series of the precipitation extremes are higher between 1990 and 2015 than in 1961-1990. In Thailand, the number of precipitation events declined, but they became more intense over the period 1955-2014 (Limsakul and Singhruck 2016).

Changes in climatic conditions are common phenomena in the history of the planet. Examining the proxy data of Paleocene-Eocene thermal maximum, Carmichael et al. (2018) found that changes in extreme precipitation behaviour may be decoupled from those in mean annual precipitation. Bodri and Dövényi (2004) reconstructed the formation of the temperature conditions of the Carpathian Basin for the past two millennia; these contained four main episodes, the last of which was a cooling period culminating around 1850 after a general warming episode. In the future, it is likely that Hungary (and elsewhere) should expect to be faced with another warming period, though not only warming, but accompanied by drastic changes in precipitation patterns in the Carpathian Region, as highlighted in several pieces of research (Kis et al. 2017; Bartholy et al. 2015; Pongrácz et al. 2014). Based on model outputs, substantially drier conditions should be expected for summer, with an increasing chance of drought. In winter, slightly more precipitation is to be expected. It may be supposed that the temporal distribution of precipitation will undergo structural changes. The frequency of heavy precipitation is projected to decrease in summer, but increase in the other seasons. These projections highlight the importance of hydrological and agricultural planning (Bartholy and Pongrácz 2010), these being those sectors most likely to be affected. Ecological impact studies often focus on the modification of vegetation patterns (Szelepcsényi et al. 2018), and the increased drought hazard in protected natural reserve territories (Ladányi et al. 2015). One of the more frequently investigated problems seems to be the impact of the precipitation in causing dynamic evolution to occur in groundwater flow systems (see, for example, Havril et al. 2018). Garamhegyi et al. (2018) investigated the periodic behaviour of the shallow groundwater level in Hungary and its link to large-scale circulation patterns. The results obtained could be used to gain an insight into possible changes in drought frequency and duration in the future. Long-term gradual changes in abiotic factors (e.g. precipitation) cause changes in soil formation processes by modifying the soil water regime, mineral composition and organic matter formation (Gelybó et al. 2018). Csáki et al. (2018) reported that increasing temperatures in the twenty-first century are projected to cause a reduction in long-term runoff that may exceed 53\% for the Zala watershed, that is, an area linked to a river with a vital connection to the waters of Lake Balaton. Such future changes represent a potentially severe risk to the agricultural sector in the region, and adaptation by the stakeholders in the sector will necessarily be very important. Li et al. (2017a) investigated how Hungarian farmers perceive climate change risk, and their willingness to adapt to it. Li et al. (2017b) point out that the adaptation strategies of the farmers to climate change are highly affected by socio-economic changes in Hungary.

The aim of the present study was to investigate changes in precipitation over the past almost one and a half centuries on a local scale, at Keszthely, a location situated in an important region for tourism, agriculture and a preservation area for the natural environment, and especially biodiversity in the WestBalaton wetland (Fig. 1). The Carpathian Basin is expected to experience extreme weather conditions with highly variable inter- and intra-annual precipitation (and air temperature) events. Changes in annual precipitation and their temporal distribution seem to be almost capricious in their extremity, carrying a risk to those areas sensitive to water scarcity. The location of the study, Keszthely, is at the north-western end of Lake Balaton (Hungary), an area particularly vulnerable to variation in precipitation on account of the shallowness of the lake (Fig. 1); any change in water level may cause impoverishment in species diversity in the lake. This theme is worthy of a serious follow-up, as permanent meteorological observations at Keszthely Meteorological Station have been carried out since 1871 . This meteorological station was among 


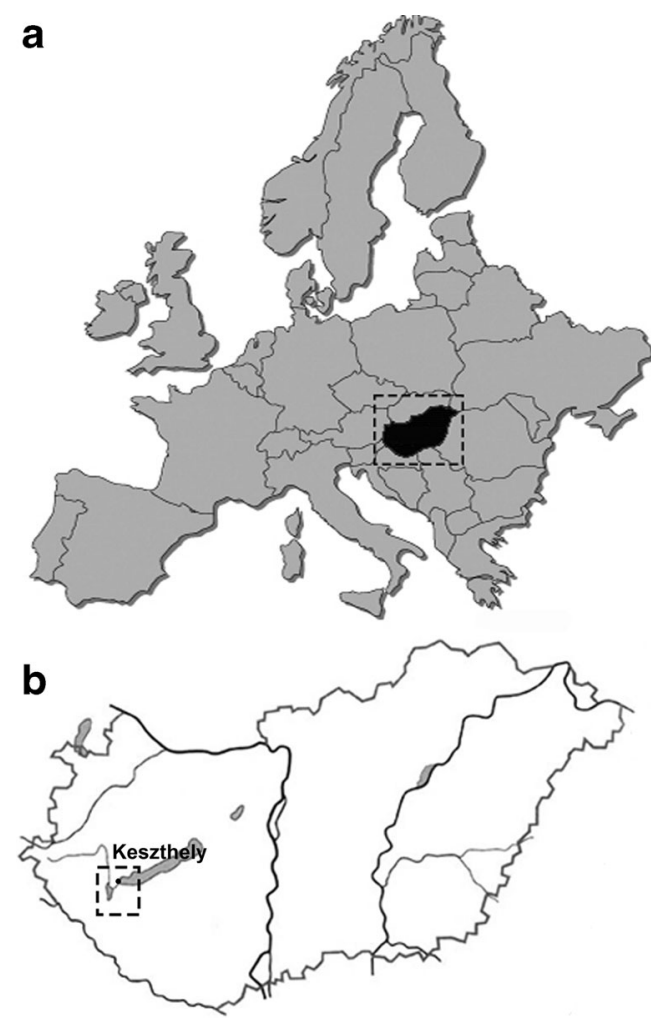

Fig. 1 Location of Keszthely $\left(46^{\circ} 44^{\prime} \mathrm{N}, 17^{\circ} 14^{\prime} \mathrm{E}\right.$, elevation $114.2 \mathrm{~m}$ above Baltic sea level) in Europe (a) and in Hungary (b) according to Anda et al. (2015)

the first to implement continuous observation in Hungary, and indeed in Europe. The results of the analysis may also be a source of reference information to specialists dealing with the on-site impacts of global warming. The consideration of almost one and half centuries of rainfall data as well as the vulnerable nature of the study site makes the analysis relevant even to an international readership.

\section{Data and methods}

\subsection{Data used}

Figures for monthly precipitation for the period 1871-2014 were analysed. The time series of yearly amounts, seasonal amounts and monthly amounts of precipitation were also examined, and an analysis was conducted with the aim of identifying change points and monotonic trends. Each time series contained 144 data. The dataset was complete, without missing data.

In the first instance, the data were measured at the longestablished Georgikon Academy of Agriculture in Keszthely, and later, at the meteorological station of the Hungarian Meteorological Service. The dataset was provided by the Department of Meteorology and Water Management of the
University of Pannonia, Georgikon Faculty (Keszthely). This dataset is special because few stations in Hungary have continuous measurements spanning more than 140 years, and also possess a detailed historical background (Kocsis and Anda 2006). The Keszthely meteorological station was one of those few, important stations in Hungary that began taking measurements right from the beginning of Hungarian meteorological observations. The record measurements remain unbroken up to the present day, in spite of the fact that the station has been moved several times. At the beginning of the period over which measurements have been taken, the rules governing the location and operation of the station were not so strict, so the observations were made in the central building of the Academy in the town centre. In 1962, the whole station was relocated to the research station of the Georgikon Agricultural Academy. Again, in 1966-because of urbanisation - the meteorological station was moved to the outskirts, near Lake Balaton, as the Observatory of the Hungarian Meteorological Service. Between 1966 and 1995, the station was located at the nearest point to the lake of all the meteorological stations of the town, and had the most frequent observation schedule. The exact position of the station was then $\mathrm{E} 17^{\circ} 14^{\prime}, \mathrm{N} 46^{\circ} 45^{\prime}$, elevation $116 \mathrm{~m}$ above Baltic sea level. Five meteorologist-technicians worked continuously in the observatory all day, providing current weather observations hourly. In 1971, an Agro-meteorological Research Station was founded within the shared framework of the Hungarian Meteorological Service and of the University of Agriculture (successor to Georgikon Agricultural Academy). This station was placed at the edge of town, and has continued taking meteorological measurements since 1995.

The current position of the Keszthely meteorological station is $\mathrm{E} 17^{\circ} 14^{\prime}, \mathrm{N} 46^{\circ} 44^{\prime}$, elevation $114.2 \mathrm{~m}$ above Baltic sea level. In the autumn of 1996, a MILOS 500 automatic meteorological station was set up at the agro-meteorological station. In the winter of 2000, the MILOS 500 automatic weather station was replaced with a QLC 50 automatic meteorological station. The automatic station forwards the measured data to the central ORACLE data set of the Hungarian Meteorological Service via the internet. QLC 50 looks at the following parameters: global radiation, velocity and direction of the wind, air temperature, air humidity, temperature of the soil at various depth $(5,10,20,50 \mathrm{~cm})$, grass temperature and precipitation amount. Until the automatisation of the measurements (1996), a Hellmann-type rain gauge was used for the measurement of precipitation. But besides the automatic measurement of the tipping bucket rain gauge, the mechanical Hellmann-type rain gauge is also still in use, because in heavy storms it provides a more precise measurement. At present, the station is under the operational jurisdiction of the Department of Meteorology and Water Management of the University of Pannonia Georgikon Faculty, and is a vital part of the Hungarian Meteorological Observation Network. 
The precipitation in Keszthely consists mainly of rain, with only a limited number of days with snow cover, averaging 32 days during winter. These snowfall events are distributed from November through March, when precipitation as snow or mixed with rain appears. As of the present, the Hungarian National Meteorological Service (OMSZ) does not attempt to correct either wind influence or snowfall. The Agrometeorological Research Station (ARS) at Keszthely is a vital part of the official observation network of the OMSZ housed in Budapest. At the same time, the station (Agrometeorological Research Station, ARS) also belongs to the Department of Meteorology and Water Management in Keszthely (University of Pannonia, Georgikon Faculty). As long as the staff of the local station is responsible for the smooth operation of instruments, including rain gauge, collected data are transferred to OMSZ for quality control before use. The ARS receives the processed precipitation data. The OMSZ uses the MASH method (Szentimrey 1999) in the homogenisation of long-term data series.

At Keszthely, as a part of the Hungarian observation network, a mechanical Hellmann-type rain gauge with an accuracy of $0.1 \mathrm{~mm}$ has been in operation since 1900. Before this time, the first installations of rain gauges between 1871 and 1900, the so called "Austrian-pattern"-type instrument was used (Nagy and Nagy 2000). The recording tipping bucket with a 10-min frequency was only installed in 1996. The top of the funnel was located at $1 \mathrm{~m}$ above the ground surface during the whole investigated period.

More than a century-long unbroken precipitation data measured by the Hellmann-type rain gauge at stations with close geographical positions may be considered exceptional. Due to the position of Keszthely on a flat lakeshore of Lake Balaton, the station's various elevations hardly changed (114.2-123.0 m) from the beginning of observations. As a result of the subjection of Keszthely to spreading urbanisation, the station displacements never exceeded 1-1.5 km. In the mid latitudes, for coherent precipitation data over flat terrain, even interpolation should yield acceptable results on scales smaller than $10 \mathrm{~km}$ (Dingman 2015). The density of precipitation stations within the Hungarian operational network, including former precipitation stations, covers these scales. The small distances between the stations, the flat area (elevation ranging from 114.2 to $123.0 \mathrm{~m}$ ) and the limited number of rain gauge types used seem to constitute a guarantee that the precipitation data were not significantly skewed or distorted during the whole observation period. The coincidence of 100-plus years of precipitation data collected using two types of rain gauge already said, which should be clear in one town with almost the same geographical positions, creates a unique opportunity for longterm precipitation series analysis. The missing precipitation data used to be replaced by data of Sármellék Airport $\left(46^{\circ} 42^{\prime} \mathrm{N} ; 17^{\circ} 10^{\prime} \mathrm{E} ; 124 \mathrm{~m}\right)$, which is the closest meteorological station to Keszthely.

\subsection{Statistical methods}

Inhomogeneity in time series can cause the incorrect interpretation of extreme events (Rahman et al. 2017), and be misleading in the interpretation of tendencies in the time series. Abrupt changes in the mean are one of the normal outcomes of inhomogeneity in time series data (Rahman et al. 2017). The importance of the homogeneity test is pointed out by Buffoni et al. (1999), and Reiter et al. (2012). Several methods can be used to detect abrupt changes: Pettitt's test is a widespread non-parametric method to detect inhomogeneity, the change point in a time series (Arikan and Kahya 2019).

The application of the Mann-Kendall non-parametric trend test is recommended by the World Meteorological Organization to detect statistically significant tendencies in environmental datasets (Irannezhad et al. 2016). The use of the Mann-Kendall trend test is widespread in the analysis of climatological and hydrological time series, because it is simple and robust, and can cope with missing values and values falling beneath the detection limit (Gavrilov et al. 2016). This non-parametric test is commonly used to detect monotonic tendencies in series of environmental data, too (Pohlert 2016). No assumption of normality is required (Helsel and Hirsh 2002). Hamed and Rao (1998) developed a modified Mann-Kendall test for autocorrelated data. The application of this modified method is presented by Amirataee et al. (2016), for example. Yue et al. (2002) investigated the power of the Mann-Kendall test in hydrological time series.

\subsubsection{Homogeneity test of the data}

The Pettitt test (Pettitt 1979) was chosen to detect inhomogeneity in the time series analysed in this research. In that research, a non-parametric approach to change-point analysis was proposed that is still widely used. This test detects shifts in the average and calculates their significance (Liu et al. 2012) in a hypothesis test. The null hypothesis is that the data are homogeneous, as against the alternative hypothesis that there is a datum at which there is a change in the data. The empirical significance level ( $p$ value) was computed using XLSTAT 2018v.5. In the present instance, this test was performed at a significance level of $5 \%$.

\subsubsection{Mann-Kendall trend test and Sen's slope estimator}

The Mann-Kendall trend test is based upon the work of Mann (1945) and Kendall (1975), and is closely related to Kendall's rank correlation coefficient. Here, the methodology is introduced, following the detailed descriptions given by Gilbert (1987) and Hipel and McLeod (1994), as summarized below.

To determine the presence of monotonic trend in a time series, the null hypothesis $\left(\mathrm{H}_{0}\right)$ of the Mann-Kendall test is that there is no monotonic trend in the series. The alternative 
hypothesis $\left(\mathrm{H}_{\mathrm{a}}\right)$ is that the data follow a monotonic trend over time. The Mann-Kendall test statistic is given as (Eq. 1):

$S=\sum_{k=1}^{n-1} \sum_{j=k+1}^{n} \operatorname{sgn}\left(x_{j}-x_{k}\right)$

where $j>k$ and

$k=1,2, \ldots, n-1$

$j=2,3, \ldots, n$

and $n$ is the number of the data.

$\operatorname{Sgn}\left(x_{j}-x_{k}\right)$ is calculated as follows (Eq. 2).

$\operatorname{sgn}\left(x_{j}-x_{k}\right)=\left\{\begin{array}{r}+1 \text { if } x_{j}-x_{k}>0 \\ 0 \text { if } x_{j}-x_{k}=0 \\ -1 \text { if } x_{j}-x_{k}<0\end{array}\right.$

Kendall (1975) proved that $S$ is asymptotically normally distributed with the following parameters (Eq. 3):

$$
\begin{aligned}
& E(S)=0 \\
& \operatorname{Var}(S)=\left\{n(n-1)(2 n+5)-\sum_{p=1}^{g} t_{p}\left(t_{p}-1\right)\left(2 t_{p}+5\right)\right\} / 18
\end{aligned}
$$

where

$g$ is the number of tied groups in the data set,

$t_{p}$ is the number of data in the $p^{\text {th }}$ tied group,

$n$ is the number of data in the time series.

A positive value for $S$ means that there is an increasing trend; a negative value for $S$ means the opposite, that there is a decreasing trend with time. For $n>10$, e.g. more than ten observations, a standard normal random variable, $Z$, can be used in the hypothesis test (Eq. 4):

$Z=\left\{\begin{array}{ccc}\frac{S-1}{[\operatorname{Var}(S)]^{1 / 2}} & \text { if } & S>0 \\ 0 & \text { if } & S=0 \\ \frac{S+1}{[\operatorname{Var}(S)]^{1 / 2}} & \text { if } & S<0\end{array}\right.$

$S$ is closely related to Kendall's rank correlation coefficient ( $\tau$ ); therefore, testing $\tau$ is the equivalent to testing $S$ (Eq. 5):

$\tau=\frac{S}{D}$

where $D$ is the possible number of observation pairs from a total of $n$ observations (Eq. 6).

$D=\left(\frac{n}{2}\right)$

In the course of the hypothesis test, a significance level of $\alpha$ $=5 \%$ was used in a two-tailed test, in which the null hypothesis is that there is no monotonic trend is the time series $\left(\mathrm{H}_{0}: \tau\right.$ $=0$ ), and the alternative hypothesis is that there is a significant monotonic trend in the time series $\left(\mathrm{H}_{\mathrm{a}}: \tau \neq 0\right)$. The empirical significance level ( $p$ value) was determined.

The presence of positive autocorrelation in the data increases the chance of detecting trends when actually none exists, and vice versa (Hamed and Rao 1998). This effect of the existence of autocorrelation in data is often ignored: Hamed and Rao (1998) supposed a modified non-parametric trend test suitable to autocorrelated data, and gave a detailed description of the modified Mann-Kendall trend test for autocorrelated data. In the present study, this type of MannKendall test was also applied to avoid the above uncertainty. This version is based on the modified variance of $S(\operatorname{Var} *(S))$ (Hamed and Rao 1998; Taxak et al. 2014) (Eq. 7)

$\operatorname{Var}^{*}(S)=\operatorname{Var}(S) \cdot \frac{n}{n_{S}^{*}}$

The correction factor $\left(\frac{n}{n_{s}^{*}}\right)$ is evaluated as follows (Taxak et al. 2014; Hamed and Rao 1998) (Eq. 8):

$\frac{n}{n_{S}^{*}}=1+\frac{2}{n^{*}(n-1) *(n-2)} \cdot \sum_{i=1}^{n-1}(n-i)(n-i-1)(n-i-2) \rho_{S}(i)(8)$

where

$\rho_{s}(i)$ is the autocorrelation between the ranks of the observations calculated after subtracting a non-parametric trend estimator such as Sen's slope estimator, and $n^{*}$ is the 'effective' number of observations to account for autocorrelation in data.

Only significant values of the ranks $\left(\rho_{s}(i)\right)$ are used as $\operatorname{Var}(S)$ is underestimated in case of presence of positive autocorrelation (Taxak et al. 2014; Hamed and Rao 1998).

In the case of the detection of a non-parametric trend, Sen's slope estimator (Sen 1968) was applied. This is a nonparametric method that can calculate the change per unit time (direction and volume). Sen's method uses a linear model to estimate the slope of the trend, and the variance of residuals should be constant in time (da Silva et al. 2015). First, $N^{\prime}$ slope estimates were calculated $(Q)$ (Eq. 9):

$Q=\frac{x_{i}^{\prime}-x_{i}}{i^{\prime}-i}$

where

$x_{i^{\prime}}$ and are the data values at times $i^{\prime}$ and $i$, respectively, and $x_{i} \quad$ where $i>i$,

$N^{\prime} \quad$ is the number of data pairs for which $i^{\prime}>i$.

If there is only one datum in each time period (Eq. 10),

$N^{\prime}=\frac{n(n-1)}{2}$

where $n$ is number of time periods (Gilbert 1987; Gocic and Trajkovic 2013). The $N^{\prime}$ values of $Q$ are ranked from smallest to largest, and the median of $Q$ values gives the slope of the 
tendency. The advantage of this method is that it limits the effect of outliers on the slope (Shadmani et al. 2012), and it is robust and free of restrictive statistical constraints (Lavagnini et al. 2011; Kocsis et al. 2017). The confidence interval of the Sen slope was estimated at a confidence level of $95 \%$.

XLSTAT (2018v.5) statistical software was used to carry out the computations.

\section{Results}

\subsection{Homogeneity test of the yearly, seasonal and monthly precipitation amounts}

Pettitt's test was used in a two-tailed test in which the null hypothesis was that there is no shift in the mean in the dataset. The alternative hypothesis was that there is a certain datum at which a change point can be detected and the mean of the dataset shifts at this break point. The empirical significance level ( $p$ value) is shown in Table 1. Statistically significant change points can be detected in spring, in winter and in October. In the time series of spring precipitation amounts, the significant shift of the mean is downward, and the break point occurs in 1942. After extensive research in the meta-data and archive information concerning the history of the measurements, no apparent explanation could be found for this change point. The same can be stated for the significant upward change point in the winter. This break point occurred in 1899. In the case of the precipitation amount dataset for October, a significant downward break point occurs in 1941. No physical reason which would explain this could be found in

Table 1 Results of the Pettitt homogeneity test ( $p$ values of the significant change points are in italics)

\begin{tabular}{llll}
\hline & Change point at year & Two-tailed test $(p$ value $)$ & Shift \\
\hline Annual & 1966 & 0.09 & \\
Spring & 1942 & $<0.0001$ & Downward \\
Summer & 1975 & 0.5722 & \\
Autumn & 1945 & 0.0934 & Upward \\
Winter & 1899 & 0.0082 & \\
Jan & 1899 & 0.123 & \\
Feb & 1920 & 0.3448 & \\
Mar & 1941 & 0.7774 & \\
Apr & 1931 & 0.077 & \\
May & 1943 & 0.0828 & \\
Jun & 1890 & 0.0828 & Downward \\
Jul & 1920 & 0.4754 & \\
Aug & 1941 & 0.4326 & \\
Sep & 1937 & 0.6022 & \\
Oct & 1941 & 0.0158 & \\
Nov & 1924 & 0.5326 & 0.5076 \\
Dec & 1899 & & \\
\hline
\end{tabular}

the archive information, and in the historical background of the measurements, the relocation of and other changes to the station did not result in change points in the time series. Significant monotonic tendencies had previously been detected in spring and autumn and in October using the Mann-Kendall trend test (Kocsis and Anda 2018). As in the time series of the autumn precipitation amount, no shift can be detected, and so the significant monotonic tendency should be accepted as fact. But in spring and October, the question arises of whether the significant monotonic trend is a consequence of the change point. The datasets were therefore divided at the break point. Only one significant break point could be detected in any of the cases. The separate parts were examined from the perspective of the monotonic trend. The shifts in the mean at the change points are given in Figs. 2, 3 and 4.

A significant downward shift can be detected in spring. The mean seasonal amount of precipitation was $180.33 \mathrm{~mm}$ in the period before the date of the break point (the red line in Fig. 2). Due to the shift in the average, the figure for the mean amount of precipitation in spring was $143.5 \mathrm{~mm}$ in the period after the break point (green line in Fig. 2). In the winter season, a significant upward shift can be statistically demonstrated, and the average amount of precipitation was $81.59 \mathrm{~mm}$ in the period before the date of the break point (the red line in Fig. 3), while it was $118.66 \mathrm{~mm}$ in the period after (the green line in Fig. 3). In October, a downward break point can be detected. The amount of monthly mean precipitation was $69.49 \mathrm{~mm}$ in the period before the date of the break point (the red line in Fig. 4), and $47.67 \mathrm{~mm}$ in the period following the shift (the green line in Fig. 4)

\subsection{Mann-Kendall trend test of the yearly, seasonal and monthly precipitation amounts}

Table 2 shows the $p$ values of the non-parametric MannKendall trend test for detecting monotonic tendencies. The tendencies were also analysed using an autocorrelated Mann-Kendall trend test, as modified according to Hamed and Rao (1998) to take into account the possibility of autocorrelation in the meteorological data.

If an autocorrelated trend test was used, a significant monotonic tendency could be detected in the annual dataset. Here, $S$ is negative, and a decreasing trend may therefore be supposed. The decreasing monotonic trend of the autumn precipitation amounts is statistically significant. But, in the case of those time series with significant change points, the divided parts do not show any significant tendency. It may therefore be concluded that in the case of October-where a previously significant decreasing trend could be detected for the whole dataset - this result was the consequence of a downward shift in the mean. Separating the time series at the significant change point, no significant trend could be recognised. The same can be concluded in the case of the spring dataset. 
Fig. 2 Significant change points and downward shifts in the mean in the precipitation amounts for spring (1871-2014)
400

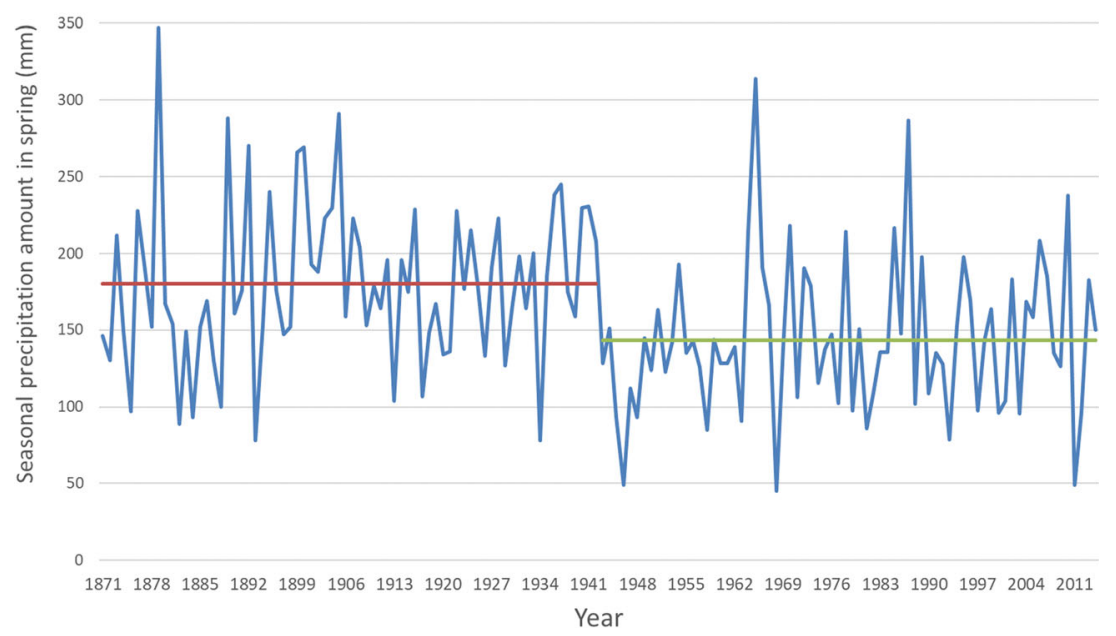

Table 3 represents the lower and upper values of the confidence intervals in Sen's slope at the 95\% probability level for significant trends. If autocorrelation is taken into account, a decreasing tendency of $0.2-0.7 \mathrm{~mm}$ per year may be discerned. In the autumn - in both simple and autocorrelated Mann-Kendall trend tests - Sen's slopes yield the same values. Between 1871 and 2014, a decrease of 0.15-0.38 mm per year can be detected in the autumn precipitation amount.

\section{Discussion}

Previous results published by the authors of the present study, and based on a simple Mann-Kendall trend test (Kocsis and Anda 2018), showed significant declining tendencies in the amounts of spring and autumn seasonal precipitation, and also in October. The question arises whether these trends are consequences of a long-term change or results of abrupt changes in the mean. A significant break point identified by Pettitt's test can be detected in the series of spring seasonal precipitation amounts and in the time series of winter and October. In the series of the seasonal amount of autumn, no inhomogeneity can be found; therefore, the significant decreasing tendency - with enhanced significance if the autocorrelation of the data is taken into account — can be accepted by a decrease of $0.15-0.38 \mathrm{~mm}$ per year. In the case of the amount of spring precipitation, the declining tendency previously observed is likely to be the consequence of an abrupt change in the average, as a significant break point was found in the time series. The direction of the shift in the mean is downward, but the parts of the time series separated at the date of the break point do not show any significant trends. In October, a significant downward break point occurred and the parts of the time series separated at the date of the break point do not sign any significant tendencies. An additional result was that no break point can be detected in the series of the annual amount of precipitation, but in the autocorrelated Mann-Kendall trend
Fig. 3 Significant change points and upward shifts in the mean in the precipitation amounts for winter (1871-2014)

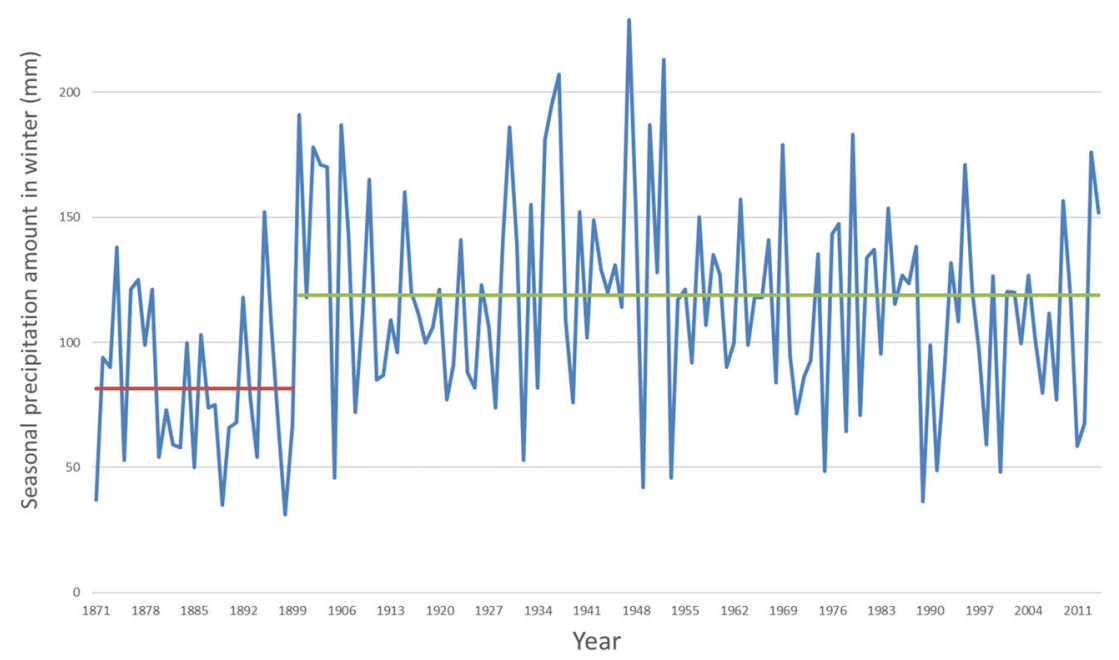


Fig. 4 Significant change points and downward shifts of the mean in the precipitation amounts for October (1871-2014)

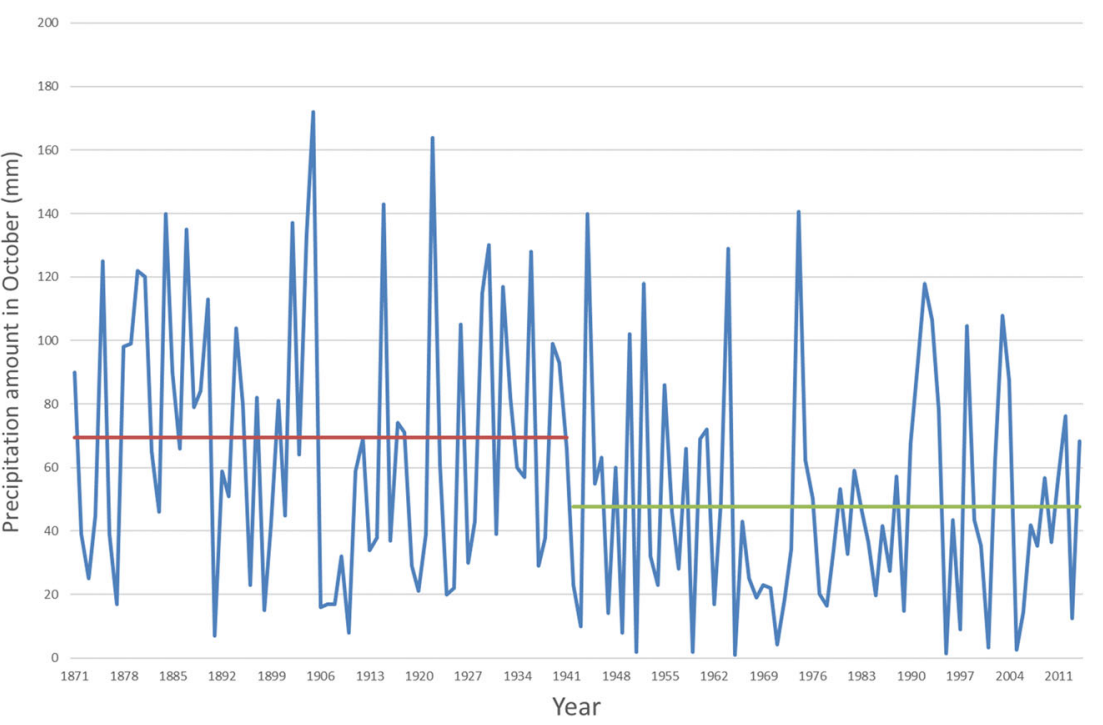

test a significant decreasing trend of $0.2-0.7 \mathrm{~mm}$ per year can be statistically shown. A significant upward shift in the mean can be detected in the winter seasonal precipitation amount. These downward and upward shifts in the mean in the case of spring and winter seasonal amounts, respectively, all lead one to suspect that changes in precipitation are also in progress in these seasons.

These results concerning ongoing changes are to a large degree consistent with the future projections of Bartholy and Pongrácz (2010), but are nonetheless in contradiction with the results for the wider region of Domokos and Tar (2003), in which significant declining trends in annual amounts of precipitation and in seasonal precipitation amounts for Hungary in the period of 1901-1998 are reported, including for winter, as well. Precipitation has the potential for great variability in space and time. Climate change has different effects on the modification of precipitation amounts all over Europe. Brázdil et al. (2012) did not find any significant change in the annual and seasonal time series of precipitation amounts over the period 1882-2010 in the Czech Republic. In Greece, a general and clear decreasing trend was detected in the annual precipitation by Feidas et al. (2007) for the period 1955-2001, with a declining tendency in winter precipitation. In central Italy, a negative but not significant trend
Table 2 Results of the simple and autocorrelated Mann-Kendall (MK) trend tests (the $p$ value of the significant monotonic tendency is in italics)

\begin{tabular}{|c|c|c|c|c|}
\hline & \multicolumn{2}{|c|}{ Two-tailed test until the change point if any } & \multicolumn{2}{|c|}{ Two-tailed test after the change point if any } \\
\hline & MK $p$ value & $\begin{array}{l}\text { Autocorrelated } \\
\text { MK } p \text { value }\end{array}$ & MK $p$ value & $\begin{array}{l}\text { Autocorrelated } \\
\text { MK } p \text { value }\end{array}$ \\
\hline Annual & 0.0899 & 0.0075 & & \\
\hline Spring & 0.0834 & 0.0834 & 0.2937 & 0.3625 \\
\hline Summer & 0.5205 & 0.546 & & \\
\hline Autumn & 0.0464 & 0.0186 & & \\
\hline Winter & 0.4528 & 0.4528 & 0.0992 & 0.0992 \\
\hline Jan & 0.4534 & 0.5863 & & \\
\hline Feb & 0.2615 & 0.2615 & & \\
\hline Mar & 0.3394 & 0.2607 & & \\
\hline Apr & 0.057 & 0.057 & & \\
\hline May & 0.0641 & 0.0152 & & \\
\hline Jun & 0.8642 & 0.8571 & & \\
\hline Jul & 0.7454 & 0.7296 & & \\
\hline Aug & 0.4545 & 0.4545 & & \\
\hline Sep & 0.3351 & 0.3513 & & \\
\hline Oct & 0.666 & 0.6658 & 0.6866 & 0.4745 \\
\hline Nov & 0.8358 & 1 & & \\
\hline Dec & 0.278 & 0.3651 & & \\
\hline
\end{tabular}


Table 3 Confidence intervals of Sen's slope for the significant tendencies at $95 \%$ confidence level

\begin{tabular}{lll}
\hline & \multicolumn{2}{l}{$95 \%$ confidence interval of Sen's slope } \\
\cline { 2 - 3 } & \multicolumn{1}{l}{ Lower limit } & Upper limit \\
\hline In autocorrelated Mann-Kendall trend test for annual data & -0.7031 & -0.2073 \\
In Mann-Kendall trend test for autumn data & -0.3803 & -0.1482 \\
In autocorrelated Mann-Kendall trend test for autumn data & -0.3803 & -0.1482 \\
\hline
\end{tabular}

can be detected in annual precipitation for the period 1951-2012, and a reduction in precipitation is evident in winter (Scorzini and Leopardi 2019). A significant decreasing tendency was statistically demonstrated for the mountainous region of Croatia in the annual and in the summer precipitation amounts by Gajic-Capka et al. (2015) for the period 1961-2010. An annual decrease in precipitation and decline in summer and autumn precipitation was detected by Alexandrov et al. (2004) in Bulgaria over the course of the 20th century. Niedzwiedz et al. (2009) analysed several precipitation time series from stations in east-central Europe (Wroclaw, Krakow, Warsaw, Lvov, Prague, Vienna and Budapest) for the time period 1850-2007 using the MannKendall trend test, and no significant trend was found in the annual precipitation series. Pötzelsberger et al. (2015) conducted analyses on the territory of Vienna Woods and found increasing tendency in winter precipitation, while a decreasing trend in summer was also found for the years 1960 to 2009. In longterm analyses, Karagiannidis et al. (2008) found a 3-year periodicity resulted by ENSO in the precipitation time series of Hungary, Austria, the Czech Republic, Slovakia and the central Mediterranean. Sun et al. (2014) detected increasing tendencies in annual precipitation time series using the Mann-Kendall test in Western, Eastern and Northern Europe (1948-2010). As against this, an examination of precipitation in Potsdam did not show significant tendency (1893-2005) (Kürbis et al. 2009).

In summary, in many parts of Europe declining tendencies in the annual amount of precipitation have been reported by several researchers, and the result of this study is consistent with this large-scale change; microclimatic conditions can, however, modify these large-scale tendencies and cause small-scale differences.

\section{Conclusion}

Precipitation is a meteorological element that varies dramatically in space and time. It displays a high degree of variability in central Europe; as a consequence, a significant changing tendency may be statistically demonstrated when the change is very large (Niedzwiedz et al. 2009). The simple MannKendall test does not show significant change in the annual precipitation amount, but the autocorrelated Mann-Kendall trend test does indicate a significant decreasing trend in the annual data by an amount of $0.2-0.7 \mathrm{~mm}$ per year. Consequently, it might be suggested that in such analyses the autocorrelation of the data should be checked. Results showed a decreasing tendency in the seasonal precipitation amounts in the autumn $(0.15-0.38 \mathrm{~mm}$ decrease per year) in accord with the literature describing the precipitation trend in the wider region of Hungary. Besides this, the shift in the mean in the spring and winter precipitation amounts might be the sign of changes and modifications that were not slow and gradual, but abrupt and drastic shifts. The effects of these shifts on the environment and on agricultural systems are similar to those of the trends. Therefore, even if significant trends cannot be detected, just a significant shift in the mean can, with the amount of precipitation in spring becoming less, and in winter the total being closer to the average, as the value of the mean has significantly changed. The reason for these shifts cannot be found in the meta-data and historical background information of the meteorological measurements used. Even in the case of Keszthely, the assumption of the presence of similar changes to those experienced and shown to have taken place in the wider region is not justifiable; despite this, it can nonetheless be concluded that signs of modifications in precipitation related to climate change can be detected in the long time series.

Acknowledgements The authors are very grateful to the data provider, the University of Pannonia Georgikon Faculty Department of Meteorology and Water Management.

Funding Information Open access funding provided by Budapest Business School - University of Applied Science (BGE).

Open Access This article is distributed under the terms of the Creative Commons Attribution 4.0 International License (http:// creativecommons.org/licenses/by/4.0/), which permits unrestricted use, distribution, and reproduction in any medium, provided you give appropriate credit to the original author(s) and the source, provide a link to the Creative Commons license, and indicate if changes were made.

\section{References}

Aguiar FC, Bentz J, Silva JMN, Fonseca AL, Swart R, Duarte Santos F, Penha-Lopes G (2018) Adaptation to climate change at local level in Europe: an overview. Environ Sci Pol 86:38-63. https://doi.org/10. 1016/j.envsci.2018.04.010

Alexandrov V, Schneider M, Koleva E, Moisselin JM (2004) Climate variability and change in Bulgaria during the $20^{\text {th }}$ century. Theor 
Appl Climatol 79:133-149. https://doi.org/10.1007/s00704-0040073-4

Amirataee B, Montaseri M, Sanikhani H (2016) The analysis of trend variations of reference evapotranspiration via eliminating the significance effect of all autocorrelation coefficients. Theor Appl Climatol 126:131-139. https://doi.org/10.1007/s00704-015-1566-z

Anda A, Soós G, da Silva JAT, Kozma-Bognar V (2015) Regional evapotranspiration from a wetland in Central Europe, in a 16-year period without human intervention. Agric For Meteorol 205:60-72. https:// doi.org/10.1016/j.agrformet.2015.02.010

Arikan BB, Kahya E (2019) Homogeneity revisited: analysis of updated precipitation series in Turkey. Theor Appl Climatol 135:211-220. https://doi.org/10.1007/s00704-018-2368-x

Bartholy J, Pongrácz R (2010) Analysis of precipitation conditions for the Carpathian Basin based on extreme indices in the 20th century and climate simulation for 2050 and 2100. Phys Chem Earth 35:43-51. https://doi.org/10.1016/j.pce.2010.03.011

Bartholy J, Pongrácz R, Kis A (2015) Projected changes of extreme precipitation using multi-model approach. Időjárás 119(2):129-142

Bodri L, Dövényi P (2004) Climate change of the last 2000 years inferred from borehole temperatures: data from Hungary. Glob Planet Chang 41(2):121-133. https://doi.org/10.1016/j.gloplacha.2003.10.001

Brázdil R, Zahradnicek P, Pisoft P, Stepanek P, Belinova M, Dobrovolny $P$ (2012) Temperature and precipitation fluctuation in the Czech Republic during the period of instrumental measurements. Theor Appl Climatol 110:17-34. https://doi.org/10.1007/s00704012-0604-3

Buffoni L, Maugeri M, Nanni T (1999) Precipitation in Italy from 1833 to 1996. Theor Appl Climatol 63(1-2):33-40. https://doi.org/10.1007/ s007040050089

Carmichael MJ, Pancost RD, Lunt DJ (2018) Changes in the occurrence of extreme precipitation events at the Paleocene-Eocene thermal maximum. Earth Planet Sci Lett 501:24-36. https://doi.org/10. 1016/j.eps1.2018.08.005

Csáki P, Szinetár MM, Herceg A, Kalicz P, Gribovszki Z (2018) Climate change impact on the water balance - case studies in Hungarian watersheds. Időjárás 122:81-99. https://doi.org/10.28974/idojaras. 2018.1.6

da Silva RM, Santos CAG, Moreira M, Corte-Real J, Silva VC, Medeiros IC (2015) Rainfall and river flow trends using Mann-Kendall and Sen's slope estimator statistical tests in the Cobres River basin. Nat Hazards 77:1205-1221. https://doi.org/10.1007/s11069-015-1644-7

Dingman SL (2015) Physical hydrology, 3rd edn. Waveland Press, Long Grove

Domonkos P, Tar K (2003) Long-term changes in observed temperature and precipitation series 1901-1998 from Hungary and their relation to larger scale changes. Theor Appl Climatol 75:131-147. https:// doi.org/10.1007/s00704-002-0716-2

Feidas H, Noulopoulou C, Makrogiannis T, Bora-Senta E (2007) Trend analysis of precipitation time series in Greece and their relationship with circulation using surface and satellite data: 1955-2001. Theor Appl Climatol 87:155-177. https://doi.org/10.1007/s00704-0060200-5

Gajic-Capka M, Cindric K, Pasaric Z (2015) Trends in precipitation indices in Croatia, 1961-2010. Theor Appl Climatol 121:167-177. https://doi.org/10.1007/s00704-014-1217-9

Garamhegyi T, Kovács J, Pongrácz R, Tanos P, Hatvani IG (2018) Investigation of the climate-driven periodicity of shallow groundwater level fluctuation in a Central-Eastern European agricultural region. Hydrogeol J 26(3):677-688. https://doi.org/10.1007/s10040017-1665-2

Gavrilov MB, Tosic I, Markovic SB, Unkasevic M, Petrovic P (2016) Analysis of annual and seasonal temperature trends using the MannKendall test in Vojvodina, Serbia. Időjárás 120(2):183-198
Gelybó G, Tóth E, Farkas C, Horel Á, Kása I, Bakacsi Z (2018) Potential impacts of climate change on soil properties. Agrochem Soil Sci 67: 121-141. https://doi.org/10.1556/0088.2018.67.1.9

Gilbert RO (1987) Statistical methods for environmental pollution monitoring. Van Nostrand Reinhold Company, NY, pp 204-240

Gocic M, Trajkovic S (2013) Analysis of changes in meteorological variables using Mann-Kendall and Sen's slope estimator statistical tests in Serbia. Glob Planet Chang 100:172-182. https://doi.org/10.1016/ j.gloplacha.2012.10.014

Hamed KH, Rao AR (1998) A modified Mann-Kendall trend test for autocorrelated data. J Hydrol 204:182-196. https://doi.org/10. 1016/S0022-1694(97)00125-X

Havril T, Tóth Á, Molson JW, Galsa A, Mádl-Szőnyi J (2018) Impacts of predicted climate change on groundwater flow systems: can wetlands disappear due to recharge reduction? J Hydrol 563:11691180. https://doi.org/10.1016/j.jhydrol.2017.09.020

Helsel DR, Hirsh RM (2002) Trend analysis. In: Techniques of waterresources investigations of the United States Geological Survey Book 4, hydrologic analysis and interpretation chapter A3: statistical methods in water resources. Chapter 12:327

Hipel KW, McLeod AI (1994) Time series modelling of water resources and environmental systems. Elsevier, Amsterdam, pp 864-866 924925

IPCC (2013) Summary for policymakers. In: Stocker TF, Qin D, Plattner G-K, Tignor M, Allen SK, Boschung J, Nauels A, Xia Y, Bex V, Midgley PM (eds) Climate Change 2013: The Physical Science Basis. Contribution of Working Group I to the Fifth Assessment Report of the Intergovernmental Panel on Climate Change. Cambridge University Press, Cambridge

Irannezhad M, Marttila H, Chen D, Klove B (2016) Century-long variability and trends in daily precipitation characteristics at three Finnish stations. Adv Clim Chang Res 7:54-69

Karagiannidis AF, Bloutsos AA, Maheras P, Sachsamanoglou C (2008) Some statistical characteristics of precipitation in Europe. Theor Appl Climatol 91:193-204. https://doi.org/10.1007/s00704-0070303-7

Kendall MG (1975) Rank correlation methods. Charles Griffin, London

Kis A, Pongrácz R, Bartholy J (2017) Multi-model analysis of regional dry and wet conditions for the Carpathian Region. Int J Climatol 37(13):4543-4560. https://doi.org/10.1002/joc.5104

Kocsis T, Anda A (2006) History of the meteorological observations at Keszthely. Published by University of Pannonia Georgikon Faculty, Keszthely ISBN 9639639079 (in Hungarian)

Kocsis T, Anda A (2018) Parametric or non-parametric: analysis of rainfall time series at a Hungarian meteorological station. Időjárás 122: 203-216. https://doi.org/10.28974/idojaras.2018.2.6

Kocsis T, Kovács-Székely I, Anda A (2017) Comparison of parametric and non-parametric time-series analysis methods on a long-term meteorological data set. Cent Eur Geol 60:316-332. https://doi. org/10.1556/24.60.2017.011

Kumar PV, Bindi M, Crisci A, Maracchi G (2013) Detection of variations in precipitation at different time scales of twentieth century at three locations of Italy. Weather and Climate Extremes 2:7-15. https://doi. org/10.1016/j.wace.2013.10.005

Kürbis K, Mudelsee M, Tetzlaff G, Brázdil R (2009) Trends in extremes of temperature, dew point, and precipitation from long instrumental series from central Europe. Theor Appl Climatol 98:187-195. https://doi.org/10.1007/s00704-008-0094-5

Ladányi ZS, Blanka V, Meyer B, Mezősi G, Rakonczai J (2015) Multiindicator sensitivity analysis of climate change effects on landscapes in the Kiskunság National Park. Hungary Ecological Indicators 58: 8-20. https://doi.org/10.1016/j.ecolind.2015.05.024

Lavagnini I, Badocco D, Pastore P, Magno F (2011) Theil-Sen nonparametric regression technique on univariate calibration, inverse regression and detection limits. Talanta 87:180-188. https://doi.org/10. 1016/j.talanta.2011.09.059 
Li S, Juhász-Horváth L, Harrison PA, Pintér L, Rounsevell MDA (2017a) Relating farmer's perceptions of climate change risk to adaptation behaviour in Hungary. J Environ Manag 185(1):21-30. https://doi. org/10.1016/j.jenvman.2016.10.051

Li S, Juhász-Horváth L, Pintér L, Rounsevell MDA, Harrison PA (2017b) Modelling regional cropping patterns under scenarios of climate and socio-economic change in Hungary. Sci Total Environ 622-623: 1611-1620. https://doi.org/10.1016/j.scitotenv.2017.10.038

Limsakul A, Singhruck P (2016) Long-term trends and variability of total and extreme precipitation in Thailand. Atmos Res 169:301-317. https://doi.org/10.1016/j.atmosres.2015.10.015

Liu L, Xu ZX, Huang JX (2012) Spatio-temporal variation and abrupt changes for major climate variables in the Taihu Basin, China. Stoch Env Res Risk A 26(4):777-791. https://doi.org/10.1007/s00477011-0547-8

Madsen H, Lawrence D, Lang M, Martinkova M, Kjeldsen TR (2014) Review of trend analysis and climate change projections of extreme precipitation and floods in Europe. J Hydrol 519:3634-3650. https:// doi.org/10.1016/j.jhydrol.2014.11.003

Mann HB (1945) Nonparametric tests against trend. Econometrica 13: 245-259

Nagy Z, Nagy J (2000) Modern measuring technics and their application in meteorology. In: Meteorological Booklets of the University No.15, ELTE Budapest:38 (In Hungarian)

Niedzwiedz T, Twardosz R, Walanus A (2009) Long-term variability of precipitation series in east central Europe in relation to circulation patterns. Theor Appl Climatol 98:337-350. https://doi.org/10.1007/ s00704-009-0122-0

Pakalidou N, Karacosta P (2018) Study of very long-period extreme precipitation records in Thessaloniki, Greece. Atmos Res 208: 106-115. https://doi.org/10.1016/j.atmosres.2017.07.029

Pettitt AN (1979) A non-parametric approach to the change-point problem. Appl Stat 28(2):126-135

Pietrapertosa F, Khokhlov V, Salvia M, Cosmi C (2018) Climate change adaptation policies and plans: a survey in 11 South East European countries. Renew Sust Energ Rev 81(2):3041-3050. https://doi.org/ 10.1016/j.rser.2017.06.116

Pinskwar I, Chorynski A, Graczyk D, Kundzewicz ZW (2019) Observed changes in extreme precipitation in Poland: 1991-2015 versus 19611990. Theor Appl Climatol 135:773-787. https://doi.org/10.1007/ s00704-018-2372-1

Pohlert T (2016) Non-parametric trends and change-point detection. https://cran.r-project.org/web/packages/trend/vignettes/trend.pdf

Pongrácz R, Bartholy J, Kis A (2014) Estimation of future precipitation conditions for Hungary with special focus on dry periods. Időjárás 118(4):305-321

Pötzelsberger E, Wolfslehner B, Hasenauer H (2015) Climate change impact on key forest functions of the Vienna Woods. Eur J Forest Res 134:481-496. https://doi.org/10.1007/s10342-015-0866-2

Rahman MA, Yunsheng L, Sultana N (2017) Analysis and prediction of rainfall trends over Bangladesh using Mann-Kendall, Spearman's rho tests and ARIMA model. Meteorog Atmos Phys 129(4):409 424. https://doi.org/10.1007/s00703-016-0479-4

Reiter A, Weidinger R, Mauser W (2012) Recent climate change at the Upper Danube - a temporal and spatial analysis of temperature and precipitation time series. Clim Chang 111:665-696. https://doi.org/ 10.1007/s10584-011-0173-y
Schroeer K, Kirchengast G, Sungmin O (2018) Strong dependence of extreme convective precipitation intensities on gauge network density. Geophys Res Lett 45:8253-8826. https://doi.org/10.1029/ 2018GL077994

Scorzini AR, Leopardi M (2019) Precipitation and temperature trends over central Italy (Abruzzo Region): 1951-2012. Theor Appl Climatol 135(3-4):959-977. https://doi.org/10.1007/s00704-0182427-3

Sen PK (1968) Estimates of the regression coefficient based on Kendall's tau. J Am Stat Assoc 63:1379-1389

Shadmani M, Marofi S, Roknian M (2012) Trend analysis in reference evapotranspiration using Mann-Kendall and Spearman's rho tests in arid regions of Iran. Water Resour Manag 26:211-224. https://doi. org/10.1007/s11269-011-9913-z

Spinoni J, Naumann G, Vogt JV, Barbosa P (2015) European drought climatologies and trends based on a multi-indicator approach. Glob Planet Chang 127:50-57. https://doi.org/10.1016/j.gloplacha. 2015.01.012

Spinoni J, Naumann G, Vogt JV (2017) Pan-European seasonal trends and recent changes of drought frequency and severity. Glob Planet Chang 148:113-130. https://doi.org/10.1016/j.gloplacha.2016.11. 013

Sun Q, Kong D, Miao QD, Yang T, Ye A, Di Z, Gong W (2014) Variations in global temperature and precipitation for the period of 1948 to 2010. Environ Monit Assess 186:5663-5679. https://doi. org/10.1007/s10661-014-3811-9

Sun Q, Miao C, Duan Q, Ashouri H, Sorooshian S, Hsu KL (2018) A review of global precipitation data sets: data sources, estimation, and intercomparisons. Rev Geophys 56:79-107. https://doi.org/10. 1002/2017RG000574

Szelepcsényi Z, Breuer H, Kis A, Pongrácz R, Sümegi P (2018) Assessment of projected climate change in the Carpathian Region using the Holdridge life zone system. Theor Appl Climatol 131(12):593-610. https://doi.org/10.1007/s00704-016-1987-3

Szentimrey T (1999) Multiple Analysis of Series for Homogenization (MASH). Proceedings of the 2nd Seminar for Homogenization of Surface Climatological Data, Budapest, Hungary; WMO, WCDMP 41:27-46

Taxak AK, Murumkar AR, Arya DS (2014) Long term spatial and temporal rainfall trends and homogeneityanalysis in Wainganga basin, Central India. Weather and Climate Extremes 4:50-61. https://doi. org/10.1016/j.wace.2014.04.005

XLSTAT (2018) v5 free download version, Addinsoft https://www.xlstat. com/en/. Accessed 20 Sept 2018

Yue S, Pilon P, Cavadias G (2002) Power of the Mann-Kendall and Spearman's rho test for detecting monotonic trends in hydrological series. J Hydrol 259:254-271. https://doi.org/10.1016/S00221694(01)00594-7

Zhao N, Yue T, Li H, Zhang L, Yin X, Liu Y (2018) Spatio-temporal changes over Beijing-Tianjin-Hebei region, China. Atmos Res 202: 156-168. https://doi.org/10.1016/j.atmosres.2017.11.029

Publisher's note Springer Nature remains neutral with regard to jurisdictional claims in published maps and institutional affiliations. 